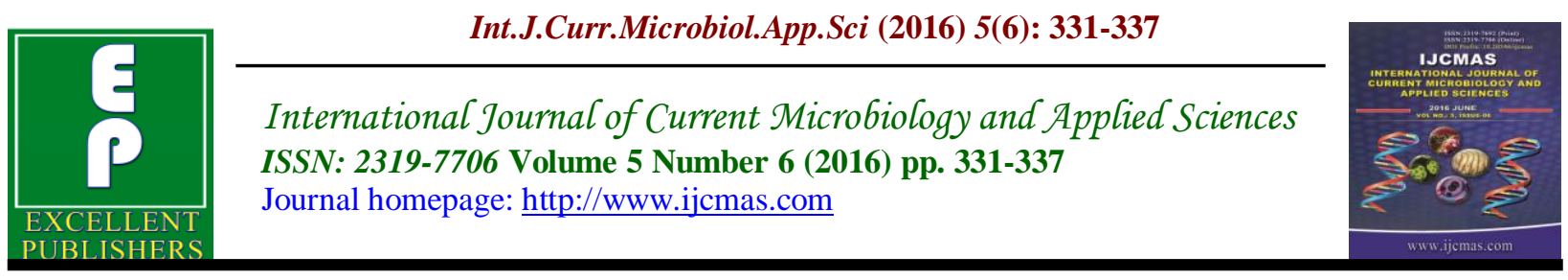

Original Research Article

http://dx.doi.org/10.20546/ijcmas.2016.506.037

\title{
In vitro Antifungal Activity of Some Plants Against Bipolaris sorokiniana (Sacc.) Shoem
}

\author{
T.R. Prashith Kekuda ${ }^{1}$, S. Akarsh ${ }^{1}$, A.S. Noor Nawaz ${ }^{2}$, M.C. Ranjitha ${ }^{1}$, \\ S.M. Darshini ${ }^{1}$ and P. Vidya ${ }^{1}$ \\ ${ }^{1}$ Department of Microbiology, S.R.N.M.N College of Applied Sciences, N.E.S campus, \\ Balraj Urs Road, Shivamogga-577201, Karnataka, India \\ ${ }^{2}$ Department of Agricultural Microbiology, U.A.S, Agriculture College, Dharwad-580005, \\ Karnataka, India \\ *Corresponding author
}

\begin{tabular}{|c|c|}
\hline & A B S T R A C T \\
\hline $\begin{array}{l}\text { Ke y w o r d s } \\
\text { Bipolaris } \\
\text { sorokiniana, } \\
\text { Root rot, } \\
\text { Plant extracts, } \\
\text { Poisoned food } \\
\text { technique. }\end{array}$ & $\begin{array}{l}\text { Bipolaris sorokiniana (Sacc.) Shoem. is a serious pathogen of wheat and } \\
\text { causes root rot disease. The present study was carried out to determine } \\
\text { inhibitory activity of } 40 \text { extracts from } 37 \text { plants belonging to } 34 \text { genera and } \\
19 \text { families against } \text { B. sorokiniana by Poisoned food technique. All extracts } \\
\text { exhibited marked antifungal activity in terms of inhibition of mycelial } \\
\text { growth of fungus. The percentage inhibition of fungus caused by extracts } \\
\text { ranged between } 54 \text { to } 91 \% \text {. Extract of } 8 \text { plants viz., Curcuma aromatica, } \\
\text { Atylosia lineata, Butea superba, Striga gesnerioides, Calceolaria mexicana, }\end{array}$ \\
\hline Article Info & Adhatoda vasica, Conyza stricta and Smithia sensitiva exhibited highest \\
\hline $\begin{array}{l}\text { Accepted: } \\
15 \text { May } 2016 \\
\text { Available Online: } \\
10 \text { June } 2016\end{array}$ & $\begin{array}{l}\text { inhibitory activity ( }>90 \% \text { inhibition). Least antifungal effect was displayed } \\
\text { by extract of Emilia sanchifolia ( } 54 \% \text { inhibition). These extracts appear } \\
\text { promising antifungal agents. Further investigations in field conditions are to } \\
\text { be carried out. }\end{array}$ \\
\hline
\end{tabular}

\section{Introduction}

Fungi are important in agriculture as they are involved in improvement of crop production as well as destruction of crops. Among plant pathogens, fungi are the important pathogens as they cause huge number of diseases in crops leading to economic loss. Various approaches are used for controlling phytopathogenic fungi. The use of synthetic fungicides is the commonly used strategy. However, the use of these conventional synthetic chemicals resulted in environmental pollution, soil and ground water toxicity, development of resistant strains of the fungal pathogens, slow biodegradation and effect on non-target organisms including humans. On entry into humans, these chemicals cause severe health effects. Control of phytopathogens using botanicals is one of the best alternatives for chemical fungicides. They are cost effective, 
safer and ecofriendly. Higher plants are shown to possess fungitoxic activity against a range of pathogenic fungi (Seema et al., 2011; Boonsang et al., 2014; Kambar et al., 2014; Rafi and Dawar, 2015; Shweta et al., 2015; Parveen et al., 2016).

Wheat is one among the staple cereal food crops consumed in most parts of the world. The production of crop is threatened by several disease causing agents. Bipolaris sorokiniana (Sacc.) Shoem is a serious pathogen of wheat. It causes disease symptoms such as root rot, leaf blight, seedling blight and spot blotch. The pathogen affects seed germination and seedling emergence and causes considerable reduction in grain yield. The disease is a serious threat for wheat cultivation especially in wet subtropical climatic regions. High temperature and high humidity favors for the disease outbreak. The initial symptoms of root rot originate on young seedlings from inoculum carried on the seed or from soilborne conidia near the seedling. Dark brown lesions are formed on outer coleoptile tissue and/or on the leaf base. Lesions may unite into long areas of necrotic brown tissue. The entire seedling may die in severe infection. In most cases, the seedling will survive but plant growth is stunted.

The management of disease is usually achieved by using chemicals. Plant extracts and plant based formulations appear promising in the control of phytopathogenic fungi including $B$. sorokiniana (Mathre et al., 2003; Salehpour et al., 2005; Akhter et al., 2006; Acharya et al., 2011; Hasan et al., 2012; Perelló et al., 2013a; Hossain et al., 2015; Bahadar et al., 2016). In the present study, we determined inhibitory effect of extracts from 37 plants collected from different places of Karnataka, India.

\section{Materials and Methods}

\section{Collection and Identification of Plants}

A total of 37 plants belonging to 34 genera and 19 families used in this study were collected from different places of Karnataka viz., Lakkavalli, Shankaraghatta, Mullayanagiri, Bababudangiri, Sagara, Chikkamagalure, Varadahalli, Haniya and Thirthahalli. Identification of plants was made by referring standard flora (Saldhana and Nicolson, 1978; Yoganarasimhan et al., 1981; Bhat, 2014) and with the help of taxonomists. Table 1 presents details of the plants viz., name, family and parts of the plants used.

\section{Extraction}

The collected plants were washed using clean water to remove adhering matter. The plant materials were dried under shade to prevent loss of volatile constituents and powdered in a blender. Extraction of powdered plant materials was done by simple maceration process where a known quantity of material $(10 \mathrm{~g})$ was transferred into clean conical flask containing $100 \mathrm{ml}$ of methanol. The flasks were sealed and left for 48 hours with stirrings done occasionally. The contents of flasks were filtered through Whatman No. 1 filter paper and the filtrates were evaporated to dryness in oven at $50^{\circ} \mathrm{C}$ (Kekuda et al., 2015).

\section{Antifungal Activity of Extracts}

Suppressive effect of extracts of selected plants on radial mycelial growth of $B$. sorokiniana was determined by Poisoned food technique. Control (without extract) and poisoned ( $2 \mathrm{mg}$ extract/ml of medium) Potato dextrose agar plates were aseptically inoculated with well sporulated culture of fungus by point inoculation method. The 
plates were incubated at $28^{\circ} \mathrm{C}$ for 5 days. The diameter of radial growth of fungus on plates was measured using a ruler in mutual perpendicular directions. Antifungal effect of extracts in terms of suppression of mycelial growth of fungus was determined using the formula:

Inhibition of radial growth $(\%)=(\mathrm{C}-\mathrm{T} / \mathrm{C})$ $\mathrm{x} 100$, where $\mathrm{C}$ and $\mathrm{T}$ denotes the diameter of fungal colonies on control and poisoned plates respectively (Kekuda et al., 2015).

\section{Results and Discussion}

The crop cultivation and the development of human civilization have been closely linked. Diseases of crops became a serious concern to mankind ever since plants have been cultivated for various needs, in particular for consumption. At the end of the $19^{\text {th }}$ and the beginning of the $20^{\text {th }}$ century, chemical protection measures were developed which were proven to be so effective in reducing disease incidence. However, a few years later, emergence of resistant strains of fungal pathogens have been observed. Fungi exhibit resistance to chemicals by mutations or by various mechanisms that are induced by sublethal fungicide stress (Deising et al., 2008; Hahn, 2014). Moreover, the usage of fungicides of chemical origin resulted in environmental pollution and toxic effects on non-target organisms including humans. High cost, possible adverse health effects and environmental pollution aspects of these fungicides triggered immense interest for searching alternatives for chemical fungicides. Botanicals are shown to be one of the effective alternatives for chemical agents. Researches done on several plant species have shown marked suppressive effect of plants against several phytopathogenic fungi (Seema et al., 2011;
Kambar et al., 2014; Vivek et al., 2014; Shweta et al., 2015; Parveen et al., 2016). In the present study, we evaluated the antifungal effect of 40 extracts from 37 plants against the fungus $B$. sorokiniana. Table 2 and Figure 1 depict the inhibitory activity (\%) of extracts against mycelial growth of the test fungus. All extracts were effective in inhibiting the mycelial growth of the fungus but to a varied extent. An inhibition of $>50 \%$ was recorded in case of all extracts. The percentage inhibition of test fungus by extracts was in the range $54.16 \%$ to $91.66 \%$. An inhibition of 60 to $70 \%$ was exhibited by extract of E. mysoriensis. Extract from six plants displayed an inhibitory activity in the range 70 to $80 \%$. 24 out of 40 extracts showed inhibitory activity in the range 80 to $90 \%$. Extract from 8 plants viz., $C$. aromatica, A. lineata, $B$. superba, S. gesnerioides, $C$. Mexicana, $A$. vasica (leaf), $C$. stricta and $S$. sensitiva exhibited highest activity i.e., $91.66 \%$ inhibition of the fungus. Least inhibitory activity was observed in case of $E$. sanchifolia $(54.16 \%)$. Similar studies on inhibitory activity of plants against $B$. sorokiniana have been carried out by some researchers. Extracts of Vinca rosea and Azadirachta indica exhibited inhibitory activity against germination of spores of $B$. sorokiniana (Alam et al., 2002). A study by Akhter et al. (2006) showed the efficacy of some plant extracts to inhibit germination of spores of $B$. sorokiniana. Extract of Adhatoda vasica and Zingiber officinale were shown to cause $100 \%$ inhibition of spore germination. In our study, leaf and flower extract of $A$. vasica exhibited marked inhibition of mycelial growth of $B$. sorokiniana. The studies carried out by Perelló et al. (2013a and 2013b) showed the efficacy of allicin and garlic juice containing allicin to inhibit $B$. sorokiniana. 
Table.1 Plants selected in this study

\begin{tabular}{|c|c|c|c|c|c|c|c|}
\hline $\begin{array}{l}\text { Sl. } \\
\text { No. }\end{array}$ & Name & Family & $\begin{array}{l}\text { Part } \\
\text { used }\end{array}$ & $\begin{array}{l}\text { Sl. } \\
\text { No. }\end{array}$ & Name & Family & $\begin{array}{l}\text { Part } \\
\text { used }\end{array}$ \\
\hline 1 & $\begin{array}{l}\text { Strobilanthes } \\
\text { kunthiana } \\
\text { T.Anderson ex } \\
\text { Benth. }\end{array}$ & Acanthaceae & Leaf & 20 & $\begin{array}{l}\text { Emilia sanchifolia } \\
\text { (L.) DC. ex DC. }\end{array}$ & Compositae & $\begin{array}{l}\text { Whole } \\
\text { plant }\end{array}$ \\
\hline 2 & $\begin{array}{l}\text { Luisia macrantha } \\
\text { Blatt. McCann. }\end{array}$ & Orchidaceae & $\begin{array}{l}\text { Whole } \\
\text { plant }\end{array}$ & 21 & $\begin{array}{l}\text { Striga } \\
\text { gesnerioides } \\
\text { (Willd.) Vatke }\end{array}$ & Orobanchaceae & $\begin{array}{l}\text { Whole } \\
\text { plant }\end{array}$ \\
\hline 3 & $\begin{array}{l}\text { Dendrobium } \\
\text { herbaceum Lindl. }\end{array}$ & Orchidaceae & $\begin{array}{l}\text { Whole } \\
\text { plant }\end{array}$ & 22 & $\begin{array}{l}\text { Calceolaria } \\
\text { Mexicana } \text { Benth. }\end{array}$ & Calceolariaceae & $\begin{array}{l}\text { Whole } \\
\text { plant }\end{array}$ \\
\hline 4 & $\begin{array}{l}\text { Oberonia } \\
\text { brunoniana Wight }\end{array}$ & Orchidaceae & $\begin{array}{l}\text { Whole } \\
\text { plant }\end{array}$ & 23 & $\begin{array}{l}\text { Strobilanthes } \\
\text { sessilis Nees }\end{array}$ & Acanthaceae & Leaf \\
\hline 5 & $\begin{array}{l}\text { Bulbophyllum } \\
\text { neilgherrense } \\
\text { Wight }\end{array}$ & Orchidaceae & $\begin{array}{l}\text { Whole } \\
\text { plant }\end{array}$ & 24 & $\begin{array}{l}\text { Argyreia speciosa } \\
\text { (L. f.) Sweet }\end{array}$ & Convolvulaceae & $\begin{array}{l}\text { Leaf and } \\
\text { flower }\end{array}$ \\
\hline 6 & $\begin{array}{l}\text { Bulbophyllum } \\
\text { fischeri Seidenf. }\end{array}$ & Orchidaceae & $\begin{array}{l}\text { Whole } \\
\text { plant }\end{array}$ & 25 & $\begin{array}{l}\text { Adhatoda vasica } \\
\text { Nees }\end{array}$ & Acanthaceae & $\begin{array}{l}\text { Leaf and } \\
\text { flower }\end{array}$ \\
\hline 7 & $\begin{array}{l}\text { Eria mysorensis } \\
\text { Lindl. }\end{array}$ & Orchidaceae & $\begin{array}{l}\text { Whole } \\
\text { plant }\end{array}$ & 26 & $\begin{array}{l}\text { Syzygium leatum } \\
\text { (Buch.-Ham.) } \\
\text { Gandhi }\end{array}$ & Myrtaceae & Leaf \\
\hline 8 & $\begin{array}{l}\text { Acampe } \\
\text { praemorsa } \\
\text { (Roxb.) Blatter \& } \\
\text { McCann }\end{array}$ & Orchidaceae & $\begin{array}{l}\text { Whole } \\
\text { plant }\end{array}$ & 27 & $\begin{array}{l}\text { Swertia lawii } \\
\text { Burkill }\end{array}$ & Gentianaceae & $\begin{array}{l}\text { Whole } \\
\text { plant }\end{array}$ \\
\hline 9 & $\begin{array}{l}\text { Coelogyne } \\
\text { nervosa A.Rich. }\end{array}$ & Orchidaceae & $\begin{array}{l}\text { Whole } \\
\text { plant }\end{array}$ & 28 & $\begin{array}{l}\text { Conyza stricta } \\
\text { Willd. }\end{array}$ & Compositae & $\begin{array}{l}\text { Whole } \\
\text { plant }\end{array}$ \\
\hline 10 & $\begin{array}{l}\text { Vanda roxburghii } \\
\text { R.Br. }\end{array}$ & Orchidaceae & $\begin{array}{l}\text { Whole } \\
\text { plant }\end{array}$ & 29 & $\begin{array}{l}\text { Hoya wightii } \\
\text { Hook.f. }\end{array}$ & Apocyanaceae & Leaf \\
\hline 11 & $\begin{array}{l}\text { Pholidota } \\
\text { imbricata Lindl. }\end{array}$ & Orchidaceae & $\begin{array}{l}\text { Whole } \\
\text { plant }\end{array}$ & 30 & $\begin{array}{l}\text { Hoya ovalifolia } \\
\text { Wight \& Arn. }\end{array}$ & Apocyanaceae & Leaf \\
\hline 12 & $\begin{array}{l}\text { Nardostachys } \\
\text { jatamansi (D. } \\
\text { Don) DC. }\end{array}$ & Caprifoliaceae & Rhizome & 31 & $\begin{array}{l}\text { Leucas } \\
\text { marruboides Desf. }\end{array}$ & Labiatae & Root \\
\hline 13 & $\begin{array}{l}\text { Curcuma } \\
\text { aromatica Salisb. }\end{array}$ & Zingiberaceae & Rhizome & 32 & $\begin{array}{l}\text { Smithia sensitiva } \\
\text { Aiton }\end{array}$ & Leguminosae & $\begin{array}{l}\text { Whole } \\
\text { plant }\end{array}$ \\
\hline 14 & $\begin{array}{l}\text { Putranjiva } \\
\text { roxburghii Wall }\end{array}$ & Putranjivaceae & Seed & 33 & $\begin{array}{l}\text { Crotalaria filipes } \\
\text { Benth. }\end{array}$ & Leguminosae & $\begin{array}{l}\text { Whole } \\
\text { plant }\end{array}$ \\
\hline 15 & $\begin{array}{l}\text { Fahrenheitia } \\
\text { zeylanica } \\
\text { (Thwaites) Airy } \\
\text { Shaw }\end{array}$ & Euphorbiaceae & Leaf & 34 & $\begin{array}{l}\text { Polyalthia } \\
\text { longifolia (Sonn.) } \\
\text { Thwaites }\end{array}$ & Annonaceae & $\begin{array}{l}\text { Ripe and } \\
\text { unripe } \\
\text { pericarp }\end{array}$ \\
\hline 16 & $\begin{array}{l}\text { Helichrysum } \\
\text { buddledoides } \mathrm{DC} .\end{array}$ & Compositae & $\begin{array}{l}\text { Whole } \\
\text { plant }\end{array}$ & 35 & $\begin{array}{l}\text { Maesa indica } \\
\text { (Roxb.) A. DC. }\end{array}$ & Primulaceae & Leaf \\
\hline 17 & $\begin{array}{l}\text { Atylosia lineata } \\
\text { Wt. \& Arn. }\end{array}$ & Leguminosae & Leaf & 36 & $\begin{array}{l}\text { Anaphalis lawii } \\
\text { (Hook.f.) Gamble }\end{array}$ & Compositae & $\begin{array}{l}\text { Whole } \\
\text { plant }\end{array}$ \\
\hline 18 & $\begin{array}{l}\text { Butea superba } \\
\text { Roxb. }\end{array}$ & Leguminosae & Leaf & & & & \\
\hline 19 & $\begin{array}{l}\text { Coscinium } \\
\text { fenestratum } \\
\text { (Goetgh.) Colebr. }\end{array}$ & Menispermaceae & Stem & 37 & $\begin{array}{l}\text { mysorense } \\
\text { B.Heyne ex Wight } \\
\& \text { Arn. }\end{array}$ & Hypericaceae & Leaf \\
\hline
\end{tabular}


Table.2 Inhibitory activity of extract of selected plants against B. sorokiniana

\begin{tabular}{|c|c|c|c|c|c|}
\hline $\begin{array}{l}\text { Sl. } \\
\text { No. }\end{array}$ & Treatment & $\begin{array}{c}\text { Inhibition } \\
(\%)\end{array}$ & $\begin{array}{l}\text { Sl. } \\
\text { No. }\end{array}$ & Treatment & $\begin{array}{c}\text { Inhibition } \\
(\%)\end{array}$ \\
\hline 1 & S. kunthiana & 87.50 & 21 & S. gesnerioides & 91.66 \\
\hline 2 & L. macrantha & 87.50 & 22 & C. Mexicana & 91.66 \\
\hline 3 & D. herbaceum & 87.50 & 23 & S. sessilis & 83.33 \\
\hline 4 & O. brunoniana & 79.16 & 24 & A. speciosa leaf & 87.50 \\
\hline 5 & B. neilgherrense & 70.33 & 25 & A. speciosa flower & 83.33 \\
\hline 6 & B. fischeri & 79.16 & 26 & A. vasica leaf & 91.66 \\
\hline 7 & E. mysoriensis & 62.50 & 27 & A. vasica flower & 87.50 \\
\hline 8 & A. praemorsa & 75.00 & 28 & S. leatum & 83.33 \\
\hline 9 & C. nervosa & 77.08 & 29 & S. lawii & 87.50 \\
\hline 10 & V. roxburghii & 85.41 & 30 & C. stricta & 91.66 \\
\hline 11 & P. imbricate & 79.16 & 31 & H. wightii & 83.33 \\
\hline 12 & N. jatamansi & 89.58 & 32 & H. ovalifolia & 87.50 \\
\hline 13 & C. aromatica & 91.66 & 33 & L. marruboides & 89.58 \\
\hline 14 & P. roxburghii & 87.50 & 34 & S. sensitiva & 91.66 \\
\hline 15 & F. zeylanica & 87.50 & 35 & C. filipes & 87.50 \\
\hline 16 & H. buddledoides & 87.50 & 36 & $P$. longifolia ripe pericarp & 85.41 \\
\hline 17 & A. lineata & 91.66 & 37 & P. longifolia unripe pericarp & 83.33 \\
\hline 18 & B. superba & 91.66 & 38 & M. indica & 83.33 \\
\hline 19 & C. fenestratum & 89.58 & 39 & H. mysoriensis & 87.50 \\
\hline 20 & E. sanchifolia & 54.16 & 40 & A. lawii & 81.25 \\
\hline
\end{tabular}

Fig.1 Range of mycelial inhibition of B. sorokiniana by extracts

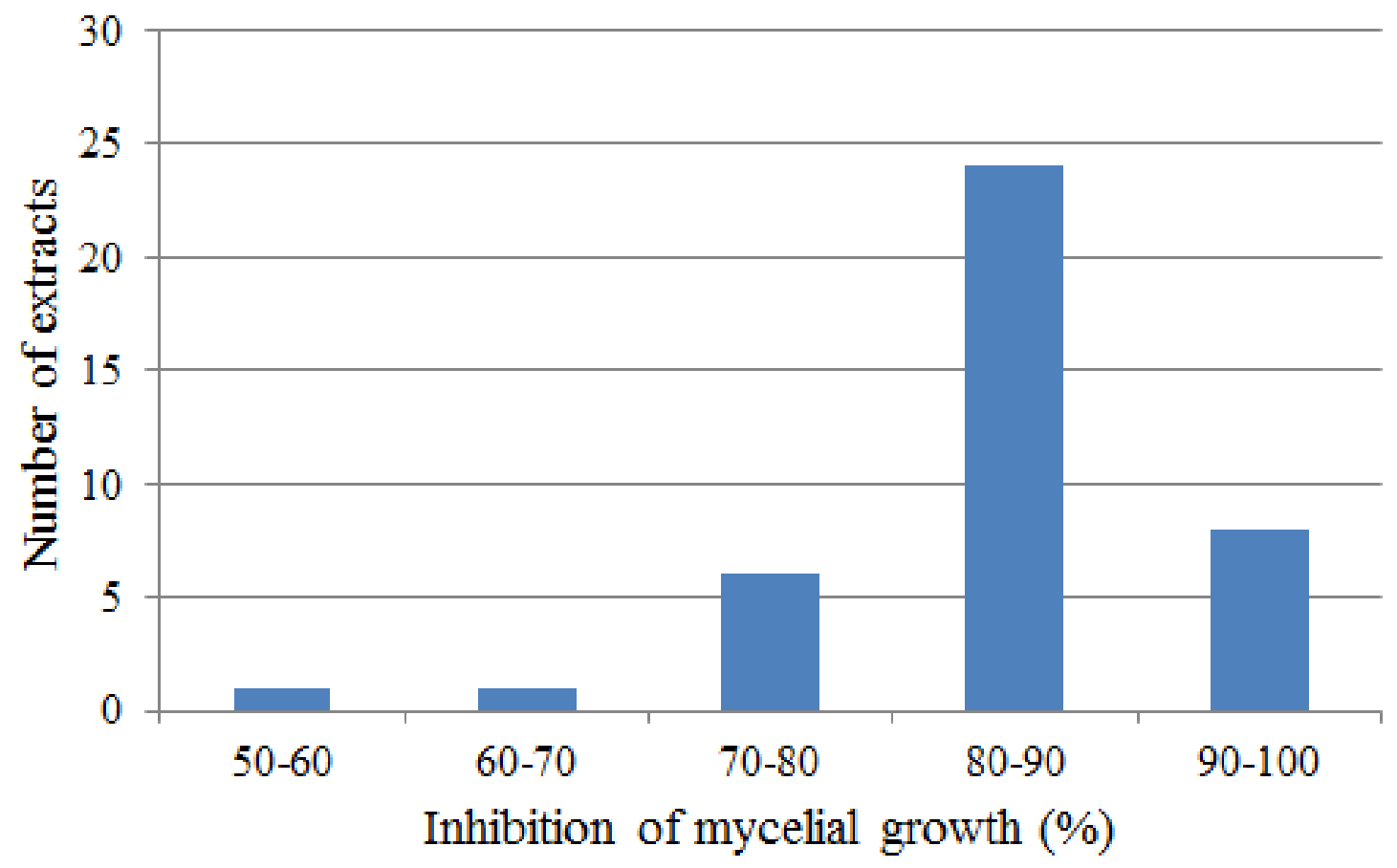


Study of Hasan et al. (2012) revealed dose dependent inhibition of $B$. sorokiniana by extract of 5 plants. Hossain et al. (2015) showed antifungal efficacy of 13 plants against $B$. sorokiniana. More recently, essential oil of flowering buds and extracts from leaf, bark and flowering buds of Eucalyptus camaldulensis were shown to exhibit potent inhibitory activity against mycelial growth and spore germination of $B$. sorokiniana (Bahadar et al., 2016).

In conclusion, botanical extracts are known to exhibit potent inhibitory activity against a wide range of phytopathogenic fungi and can be considered as a promising alternative for chemical fungicides. In the present study, all extracts have shown to exhibit marked antifungal activity against $B$. sorokiniana, causal agent of root rot of wheat. These plants can be used to control root rot disease of wheat. From the observations of the present study, it can be suggested that investigations on antifungal effect of these botanicals are to be carried out in field conditions to develop fungicidal formulations.

\section{Acknowledgements}

Authors thank Principal, S.R.N.M.N College of Applied Sciences and N.E.S, Shivamogga for providing facilities and moral support to conduct research. Authors thank Dr. E.S.K. Udupa, Prof. D. Rudrappa and Mrs. Ashwini H.S for helping in plant identification.

\section{References}

Acharya, K., Dutta, A.K., Pradhan, P. 2011. Bipolaris sorokiniana (Sacc.) Shoem.: The most destructive wheat fungal pathogen in the warmer areas. Australian J. Crop Sci., 5(9): 10641071.

Akhter, N., Begum, M.F., Alam, S., Alam, M.S. 2006. Inhibitory effect of different plant extracts, cow dung and cow urine on conidial germination of Bipolaris sorokiniana. J. Biosci., 14: 87-92.

Alam, S., Akhter, N., Begum, M.F., Banu, S.M., Islam, R.M., Chowdhury, A.N., Alam, M.S. 2002. Antifungal activities (In vitro) of some plant extracts and smoke on four fungal pathogens of different hosts. Pakistan J. Biol. Sci., 5(3): 307-309.

Bahadar, K., Munir, A., Asad, S. 2016. Management of Bipolaris Sorokiniana the causal pathogen of spot blotch of wheat by Eucalyptus extracts. J. Plant Pathol. Microbiol., 7: 326.

Bhat, G.K. 2014. Flora of South Kanara (Dakshina Kannada and Udupi Districts of Karnataka). Aakriti Prints, Mangalore.

Boonsang, N., Dethoup, T., Singburaudom, N., Gomes, N.G.M., Kijjoa, A. 2014. In vitro antifungal activity screening of crude extracts of soil fungi against plant pathogenic fungi. $J$. Biopesticides, 7(2): 156-166.

Deising, H.B., Reimann, S., Pascholati, S.F. 2008. Mechanisms and significance of fungicide resistance $\dagger$. Brazilian $J$. Microbiol., 39: 286-295.

Hahn, M. 2014. The rising threat of fungicide resistance in plant pathogenic fungi: Botrytis as a case study. $J$. Chem. Biol., 7(4): 133-141.

Hasan, M.M., Ahmed, F., Islam, M.R. 2012. In vitro effect of botanical extracts and fungicides against Bipolaris sorokiniana, causal agent of leaf blotch of barley. J. Agroforestry and Environ., 6(1): 83-87.

Hossain, M.M., Hossain, I., Khalequzzaman, K.M. 2015. Effect of seed treatment with biological control agent against Bipolaris leaf blight. Int. J. Scientific Res. Agri. Sci., 2(7): 151-158.

Kambar, Y., Manasa, M., Vivek, M.N., 
Kekuda, P.T.R. 2014. Inhibitory effect of some plants of Western Ghats of Karnataka against Colletotrichum capsici. Sci. Technol. Arts Res. J., 3(2): 76-82.

Kekuda, P.T.R., Akarsh, S., Darshini, S.M., Prafulla, D., Raghavendra, H.L. 2015. Antiradical and antimicrobial activity of Atylosia lineata Wt. and Arn. Sci. Technol. Arts Res. J., 4(3): 180-183.

Mathre, D.E., Johnston, R.H., Grey, W.E. 2003. Diagnosis of common root rot of wheat and barley. Online. Plant Health Progress, doi:10.1094/PHP-20030819-01-DG.

Parveen, S., Wani, A.H., Bhat, M.Y., Koka, J.A. 2016. Biological control of postharvest fungal rots of rosaceous fruits using microbial antagonists and plant extracts-a review. Czech Mycol., 68(1): 41-66.

Perelló, A., Noll, U., Slusarenko, A.J. 2013a. In vitro efficacy of garlic extract to control fungal pathogens of wheat. $J$. Med. Plants Res., 7(24): 1809-1817.

Perelló, A., Gruhlke, M., Slusarenko, A.J. 2013b. Effect of garlic extract on seed germination, seedling health, and vigour of pathogen-infested wheat. $J$. Plant Protection Res., 53(4): 317-323.

Rafi, H., Dawar, S. 2015. Evaluation of effective doses for bio priming of leguminous and nonleguminous seeds with microbial antagonists and plant extracts in the management of root rot fungi and promotion of plants. J. Plant Pathol. Microbiol., S4: 002.

Saldhana, C.J., Nicolson, D.H. 1978. Flora of Hassan District, Karnataka, India. Amerind Publishing Co. Pvt. Ltd., New Delhi.

Salehpour, M., Etebarian, H.R., Roustaei, A., Khodakaramian, G., Aminian, H. 2005. Biological control of common root rot of wheat (Bipolaris sorokiniana) by Trichoderma isolates. Plant Pathol. J., 4(1): 85-90.

Seema, M., Sreenivas, S.S., Rekha, N.D., Devaki, N.S. 2011. In vitro studies of some plant extracts against Rhizoctonia solani Kuhn infecting FCV tobacco in Karnataka Light Soil, Karnataka, India. J. Agri. Technol., 7(5): 1321-1329.

Shweta, S.D., Sudeshna, C.S., Rashmi, K., Vrushala, P.S., Kekuda, P.T.R. 2015. Antifungal efficacy of some epiphytic orchids of Karnataka, India. Scholars J. Agri. Vet. Sci., 2(3B): 266-269.

Vivek, M.N., Manasa, M., Kambar, Y., Nawaz, N.A.S., Vinayaka, K.S., Kekuda, P.T.R. 2014. Antifungal activity of some plants of Western Ghats of Karnataka against Sclerotium rolfsii. Indian J. Adv. Plant Res., 1(4): 29-33.

Yoganarasimhan, S.N., Subramanyam, K., Razi, B.A. 1981. Flora of Chikmagalur district. International Book Distributors, Dehra Dun. Pp 250.

\section{How to cite this article:}

Prashith Kekuda, T.R., S. Akarsh, A.S. Noor Nawaz, M.C. Ranjitha, S.M. Darshini and Vidya, P. 2016. In vitro Antifungal Activity of Some Plants Against Bipolaris sorokiniana (Sacc.) Shoem. Int.J.Curr.Microbiol.App.Sci. 5(6): 331-337. doi: http://dx.doi.org/10.20546/ijcmas.2016.506.037 